DOI: 10.36108/ssan/6991.08.0110

\title{
SOCIAL SCIENCE AS EMPOWERMENT: SOME REFLECTIONS ON THE SOCIAL SCIENCES AND THE CHALLENGE OF NATIONAL DEVELOPMENT
}

\section{UkrtuIUkwu}

\section{Institute for Development Studies, University of Enugu Campus, Nigeria}

The establishment of a fellowship means the institutionalization of a community of elders in an organisation, a signification that the organisation has developed a distinct persona, some norms and traditions which are considered worthy of custody and preservation as foundations for the future, a stock of knowledge and experience which can be drawn upon to face new challenges. It is the role of fellows to preserve this heritage and to promote positive change. But, of course, a fellowship should not be a one-man band. I hope you will soon follow through what you have started by electing new fellows so as to establish the nucleus of a viable and effective body of fellows for the Council. There is no lack of suitable candidates.

This investiture is taking place at a time when the Council is reviewing its progress so far and considering how best to prepare itself for the future; that is, on the occasion of a General Assembly devoted to the further exploration of the role of the social sciences in national development. It is only fair that I embark on my new duties by reflecting on some of the critical issues. I have therefore chosen, first to comment very briefly on the performance of the Council so far, and then to explore with you some ideas on the challenge of the future.

The Social Science Council of Nigeria was founded some fourteen years ago in response to a recognised need for an organisation to promote and coordinate the efforts of social science-related institutions, so as to improve the quality of social science research and training, and enhance the contribution of the social science community to the understanding and solution of the manifold problems of the Nigerian society, economy and polity.

From the beginning the Council set itself very ambitious goals. Its inaugural Constitution spelt out twelve objectives, which may be abridged as follows:

1) to promote the development of the social sciences;

2) to encourage inter-disciplinary and multi-disciplinary approach to the study of social science problems;

3) to foster improvement of social science curricula;

4) to assess and determine research priorities and disseminate research results;

5) to coordinate the research activities of social science organisations;

6) to monitor the supply of social scientists and promote its improvement; 
7) to monitor and take steps to improve social science research $\mathrm{f}$ un $\mathrm{d}$ ing;

8) to mobilise additional research funds;

9) to publish outstanding social science research results;

10) to cooperate with African and other international agencies:

11) to work for the enhancement of the status and image of the social sciences in general and researchers in particular; and

12) to take all necessary steps to encourage and advance the social sciences in general and enhance the impact of the social sciences in public policy.

In the fourteen years of the Council's existence a lot of progress has been made in many areas. We have done very well in reaching out to the social science community at large. We have, with the support of several external agencies, succeeded in sponsoring a wide range of development-oriented research projects. I hope we can do more to publish the more significant of these surveys. It is a worrying fact, however, that although we have received generous occasional assistance from some Federal Government agencies, we have been unable so far to develop reliable domestic sources of research funding.

More fundamentally, we have yet to come to grips with the central question of the purpose of the social sciences, of the principle which should guide our concerns and their priorities, as well as of our methods and procedures. It is to this that I would like to address myself today, with particular attention to the relevance and role of the social sciences in national development.

\section{The Social Sciences Today}

The social sciences belong to the larger body of disciplines known as the Humanities, which category includes the Arts, Law and Management Studies. According to Mabogunje, the duty of the Humanities in Nigeria is to develop the free man, "who possesses an individuality of his own and a capacity to participate efficiently in every-day life, based upon a wide knowledge of life in the past and appreciation of life in the present." And according to an NUC document, the social sciences claim as their province the study of man, his environment and behaviour: and are concerned with the study of human behaviour whose operational setting is society. They try to bring the methods of science to bear on the subjects of their study.

However, the character of the social sciences in Nigeria today derives not from the enunciated ideals but from the context and processes in which they have developed. It must be recalled that under colonial rule the educational policy discouraged the teaching of the social sciences. According to Adewoye, Lord Lugard 
considered liberal education a danger to the country, producing people lacking in respect for constituted authority and traditions, hence a direct threat to political stability. Given its tendency to sharpen the critical faculty it was also thought to tend to produce an attitude of hostility on the part of the governed towards the government ${ }^{1}$.

The social sciences did not appear on the Nigerian University syllabus until 1956, ten years after Ibadan University was established.

Social science research however belongs to an older tradition, dating back to the use of social scientists, most notably anthropologists and public administrators, to study "native" populations and institutions and advise on how best to handle the problems encountered in "native administration". Thus in the early days the social sciences were unabashedly handmaidens to the imperial power. It was not until 1950 that an intellectual gloss was put on the effort by the establishment of the West African Institute of Social and Economic Research (WAISER), the forerunner of NISER (established 1957).

In his lucid and elegant exegesis, titled Social Science as Imperialism Professor Claude Ake has shown that the global pattern of Western social science - by Western scholars and their students and on developing countries - is a form of imperialism, in that:

a) it foists, or attempts to foist on developing countries, capitalist values, capitalist institutions and capitalist development;

b) it focuses social science analysis on the question of how to make the developing countries more like the West; and

c) it propagates mystification, and modes of thought and action, which serve the interest of capitalism and imperialism.

Deriving from Western social science, the social sciences in Nigeria were therefore, using Ake's words, "born in original sin". But the baby is growing, and as it acquires some free will and personal responsibility it needs in its own interest to reexamine its heritage and rethink its future. The inaugural address of the first President of the Social Science Council of Nigeria, Professor Vremudia Diejomaoh, addressed this issue. Reacting in part to the critique, he called for the promotion of a "positive" social science, a social science still basically instrumental but directed more systematically to the attainment of accepted national goals ${ }^{2}$.

Thus, as the Nigerian social sciences develop we see two streams emerging: one radical and critical, questioning the existing system, its assumptions and goals; the other pragmatic and technical, concerned with the application of "scientific methods" to the analysis of particular situations and solution of particular problems. The mainstream would appear to be the latter, which, as Jinadu explains, practices "a policy science whose goal is viewed more as a status quo/ reformist vocation than as a transformative or radically critical one"3 
In the authoritarian tradition in Nigeria, policy-making has never been a rational and ordered process informed by proper analysis of the situation and due consultation of the relevant interests. And only too often social scientists have gained prominence more by their loyalty to the current regime and their dexterity in rationalising its policies than by their ability to develop and implement sound policies. On the other hand, critics have been marginalised or demonised by Government, having neither the motivation nor the opportunity to apply their insights more positively to improving policy.

The major impact of the social science community in national development is through research and publication. In the straightened circumstances of recent years, universities have very little research funding, and social science faculties, institutes and departments less than most. Most social science research is self-sponsored and necessarily limited in scope and content. Indeed the only significant source of social research funding now is external sponsorship, whose rising profile poses evident danger for the direction, relevance and integrity of such research. We need to develop guidelines and protocols to ensure that such welcome assistance promotes rather than distorts our development research goals.

\section{The Challenge of Social Science as Empowerment}

If the social sciences are to address the problem of national development more fundamentally, we must re-focus and re-order our priorities. I beg to suggest that the basic challenge of the social sciences in Nigeria today is to increase our self-awareness as a people, to reveal our society's capabilities, to arm us as a people with the will and ability to be ourselves and realise our full potential, to inform us properly where we stand among other peoples and nations, where our interests lie and how best to promote them. In other words, the basic challenge of the social sciences is to EMPOWER us as a people, to help us know ourselves, understand our situation and needs and work effectively for improving our status and prospects. Each discipline in the social sciences has special responsibilities in its own designated areas but all must work together and with other disciplines to accomplish the common task.

I will conclude these reflections by mentioning, more or less at random, some of the issues deserving more systematic attention in selected social science disciplines. Starting with sociology, the mother of the social sciences, I consider that the time has come for our sociologists and social anthropologists to give us contemporary portraits of Nigerian society, warts and all. We need to know how the people really live, work and play in their communities, their perceptions, needs and aspirations, how they see their kin and neighbours and interact with them. The prevailing constructs on the Nigerian society are still based mainly on colonial anthropological studies and reports. They are worse than useless in informing us 
Social Science as Empowerment: Some Reflections on the Social Sciences 5

on present-day realities. And it is on present-day realities, not onon present-day -dated or mythic constructs that the evolving Nigerian society can be solidly built.

A related issue to understanding Nigerian society is, understanding the Nigerian mind. It is now fashionable to blame "The Nigerian Factor" for every failure we do not want to face up to. What is this Nigerian factor? What makes the Nigerian tick? How does the mind of the Nigerian work? And how can it be reached? How does he learn? What motivates him? How can we build on the positive character traits of the Nigerian and compensate for the negative? What are the psychological underpinnings of the Nigerian social order? How do we measure the Nigerian's intelligence? Whose instruments and standards do we use? There are so many questions to ask and we can go on and on. Unfortunately, social psychology is perhaps the most seriously under-manned disdpline in the social sciences. The pressure may be daunting, but with a little less concern with foreign theories and models and a lot more attention to basic fieldwork, case study, and documentation, a stronger foundation can be built for understanding the psychology of national development.

In economics, it seems to me that the critical question is not whether the .Nigerian economy is growing at the rate of 2 percent or 5 percent per annum but, why is its level is so low? What is it that keeps the output of the Nigerian (in real terms) one-sixteenth that of an American or one-quarter that of a Brazilian? As long as Nigeria remains locked into the existing production structures and relationships - structures that the prevailing market forces and their commanders find convenient - our economy will remain poor and subservient. We must move away from marginalization, from over-concern with money supply, exchange rates and interest rates, to facing the problems of domestic resource identification, mobilization, beneficiation and utilization. We need to know more about the circumstances, needs, and prospects of Ihe Nigerian producer - the farmer, the craftsman, the artisan, the trader, the industrialist, and the professional. In particular, we need to know more about the small-scale producer, whose activities, though assigned to the informal sector beneath official notice, critically determine the performance level of the economy as a whole. Technology is the key to development. It is nurtured and advanced in the work place, in the actual challenge of production. Our technological policy must therefore be informed by fuller knowledge of the existing realities ${ }^{4}$.

One of the most contentious issues in national development is the issue of even development and regional equity, an issue which has now become tied up with the "National Question", as the struggle for sectional interest increasingly threatens the very structure and integrity of the state. Constitutional and administrative 
expedients such as "Federal Character" and "Rotation" do not go to the roots of the problem. What are we as social scientists doing to get the facts out, to clarify the issues and contribute to their satisfactory and lasting solution?

This is an issue which calls for a multi- and inter- disciplinary approach, involving historians, sociologists, economists, political scientists, geographers and regional planners, lawyers, and experts in the management sciences, especially public finance and public administration, among others. ${ }^{5}$

Nigeria's development also depends to a significant degree on the external environment. In this regard, our approach to international affairs requires serious rethinking. For too long the nature of the world community and our place in it have been defined for us by others. If we are to play our part in the world, and indeed in our own development, more autonomously, we must begin to re-focus consciously for a Nigeriacentered worldview. We need not only to know what the World Bank or the OECD has for Nigeria, but also to understand the character of the World Bank and the OECD and why they are involved in Nigeria's development the way they are. We need to re-focus on how to use foreign linkages to serve our own purposes rather than merely react to them.

I must now address an issue which, if not taken care of, will render nugatory all our efforts in other directions for goal-oriented and sustainable development: the issue of probity, transparency and accountability in government. In a country where major public contracts - for supplies, services, and development projects etc - are awarded for multiples of their actual value (a 1978 official report put it at about ten times, but we have "progressed" since then). Removing the sleaze factor in the management of development will enable the system deliver many times - may be ten to twenty times - what is now being achieved from the abuse of our limited resources. Corruption flourishes because power corrupts and absolute power corrupts absolutely; because due process is not always laid down and where it is laid down it is seldom followed; because the people do not know what is happening; because when they do they do not sufficiently realise how much harm it does to their permanent interests and are only too happy to enjoy any immediate personal windfalls from it; because they do not expect any better, and in any case do not see what they can usefully and safely do about it. If as social scientists we can inform the public and sensitise them to the necessity for vigilance, educate them to know their rights, to demand to be informed, to insist on due process; we will empower the people to change the system to serve them rather than their rulers.

Finally, the fact must be faced that the most significant fact in our continuing underdevelopment is our loss of sovereignty as a people, first to the British, then to our own military. As concerned social scientists we should address our minds and skills to working out and promoting a lasting solution to this problem; to how we can regain our sovereignty and maintain it against all comers and for our common good". 


\section{Notes}

1. And in independent Nigeria, has not a renowned professor and education minister berated academics who teach "what they are not supposed to teach"?

2. Other SSCN presidents who have commented on the state of the social sciences include Ajayi (1988), Makinwwa-Adebusuoye (1988), and Erinosho(1991).

3. Ndongko (1994) makes very perceptive comments on the African situation.

4. For a fuller discussion of some of the issues see Ukwu 1987 and 1991.

5. I have also examined some of the issues over the years .See, for example Ukwu 1981, 1985, 1987a, and 1993.

6. In this connection, my views on military-organised transition programmes are discussed in Ukwu 1992. Nothing that has happened since has changed my conclusions.

\section{References}

Adewoye, O. (1973) "The Antecedents " in Ajayi and Tamuno 5-21

Ake, C. (1987) "The Development of the Social Sciences in Nigeria " in Alao

Diejomaoh, V.P. (1988) "Building and Developing the Nigerian Nations: The Role of a Positive Social Science" Annals of the Social Science Council of Nigeria. NO. 1, 5-13.

Erinosho, E. O. (1992) "Nigeria in a Changing World Order" Annals of the Social Science Council of Nigeria. No. 4, 4-12.

Jinadu, L. A. (1981) "Social Science as Policy Science in Nigeria: Some Theoretical and Other Considerations." in NISER

Mabogunje, A.L.(1973) "The Humanities and the Social Sciences" in Ajayi and Tamuno

Makinwa-Adebusuoye, P.K. (1988) "Aspects of the Human Factor in National Development" Annals of the Social Science Council of Nigeria No. 1,21-.25:

Ndongko, W.A. (1994) Social Science Research and Pol icy-Making in Africa: Status, Issues and Prospects" Africa Development Vol. XIX, No 1, 71-90

Ukwu, U. I. (1981) '"Research for Even Development'" Paper presented at the Seminar on Social Science Research Priorities for National Development

Organised by the Nigerian Institute of Social and Economic Research, Ibadan, June 
8 Annals of the Social Science Council of Nigeria, No. 8, January-December, 1996

(1985a) Managing National Development Enugu: IDS.

1985b "Even Development in Nigeria: An Overview" Chapter in

Nwosii EJ. (ed) Even Development in Nigeria: Problems and Prospects. Enugu, Fourth Dimension 15-58

(1987) ed. "The Nigerian Approach to Development: a Dispassionate Appraisal" Address by Guest Speaker at the 1987 Annual Dinner of the Alumni Association of the National Institute of the Association of the National Institute

(of Policy and Strategic Studies), Abeokuta

Ukwu, U. I. (1991) "The Nigerian Economic Environment: Vision for Long Term Development" Background paper for Senior Policy Seminar on Conflicts in Development organised by the Federal Ministry of Budget and Planning and the European Centre for Development Policy Management (ECDPM) in collaboration with NCEMA, Abuja, April.

(1992) "Towards a Stable and Viable Third Republic" 1992 Annual Lecture of the Ibadan Alumni Association, Anambra/Enugu States Branch, Enugu.

(1993) "The Spatial Distribution of Economic Activities in Nigeria" in Nigeria Economic Society, The National Question and Economic Development in Nigeria (Selected papers of the 1993 Annual Conference) Ibadan: NES 109-150.

Acceptance Speech at Investiture as Fellow of the Social Science Council of Nigeria (SSCN) Lagos, 25 March, 1996 